\title{
Sex Ratio at Birth: Where Did Our Female Fetus Go?
}

\author{
Gurung $\mathbf{T K}^{1 *}$, Gurung $\mathbf{R T}^{1}$, Shrestha $\mathbf{R}^{1}$, Shrestha $\mathbf{R}^{2}$ \\ ${ }^{1}$ Lecturer, Department of Obstetrics \& Gynecology \\ Gandaki Medical College \& Teaching Hospital, Pokhara, Nepal \\ ${ }^{2}$ Consultant Gynecologist, Manmohan Memorial Community Hospital, Kathmandu, Nepal
}

\section{Keywords}

Abortion, Multiparous,

Primiparous, Sex ratio.

\section{Corresponding author \\ Dr. Tika Kumari Gurung \\ Lecturer, Department of Obstetrics \& \\ Gynecology \\ Gandaki Medical College \& Teaching \\ Hospital, Pokhara, Nepal \\ Email: tikanirvana18@gmail.com}

\begin{abstract}
Objectives: The aim of the study was to determine the ratio of male to female gender at birth and compare the sex ratio between primipara and multipara women.

Methods: This is a cross sectional retrospective study done using the data available from the medical records of the patients who were admitted in the labor room of Gandaki Medical College Teaching Hospital from July 2016 to June 2017 (Shrawan 2073 to Asad 2074).

Results: In one year period, a total of 1625 women were admitted for delivery. There were 845 male and 780 female babies delivered to those women. The sex ratio calculated was 108 male births for every 100 females. When comparing the sex ratios at birth for primipara, multipara with previous abortions and fetal death and mulipara with no history of abortions and fetal death, the sex ratio was $81.75,125.89$ and 120.16 respectively.

Conclusions: Overall there were more male births than female. But in primiparous women more female babies were born unlike in multipara. There is definitely a need of in depth study to identify the cause for the skewed value. The society needs to acknowledge that high sex ratios at birth will adversely affect the fertility patterns causing the imbalance in the overall development of community.
\end{abstract}

\section{INTRODUCTION}

The sex of the baby has always been a prime importance in our male dominating society. Though, the perspectives of the community have changed but not much. Studies have shown that at birth most babies delivered have been males. The male to female sex ratio at conception is considered to be 50:50. But more males are born throughout the world due to higher mortality rate for female fetuses, according to a new study that focused on the sex ratio from conception to birth. The death of a female child before birth at times could be simply for being a female child in a developing world where male is preferred. Though abortion after sex determination is illegal, it still does happen and it is happening around us. Therefore it is still a matter of confusion if the sex ratio in a country like ours is a true data or not.

A study has shown that male outnumber female children at birth $^{1}$. The average sex ratio at birth is defined as the ratio of newly born male to female neonates in a population and this is considered to be around $1.05^{2}$. Nepal sex ratio at birth was at level of 1.07 ratio in 2015, which was 1.05 in 2010 , this is a change of $1.04 \%$ male births per female births as per world data atlas ${ }^{3}$.

As per World Health Organization the natural "sex ratio at birth" is considered to be around 105 which means that at birth on average, there are 105 males for every 100 females. Furthermore WHO states that if ever a country's population sex ratio does not equalize or rather exceeds the 105-threshold, it means societies with a dominating preference for male child tend to intervene in nature 
and reduce the number of born girl child by sex-selective abortion and infanticide. It is estimated that annually in India approximately six lakh girls were missed during the period 2001-2007 due to prenatal sex selection. This equates to roughly 1,600 girls a day ${ }^{4}$.

Gender bias in the sex ratio still does exist in our society. The United Nations in 2007 estimated more than 117 million girls/women "missing" in Asia alone due to sex selective abortions as per information provided by the United Nations Population Fund with Nepal ranking 11th in skewed child sex ratio.

One study showed that prior to legalization of abortion in Nepal (1998-2000), the conditional sex ratio (CSR) was 1021 (906-1150). After legalization, the CSR dropped most among educated and richer women, especially in urban areas. Just 325 girls were born for every 1000 boys among the richest urban women ${ }^{5}$. However, it is believed that a combination of sex-selective technology and a small-family culture has caused the highest sex $\operatorname{ratios}^{6,7}$.

\section{METHODS}

This retrospective study included a total of 1625 women who were admitted in the labor room at Gandaki Medical College Teaching hospital for delivery. These women were from Pokhara city and outskirts of Pokhara mostly from Tanahun, Kaski, Syangja, Gorkha, Baglung. At the time of admission, these women were in labor or admitted to terminate the pregnancy for various reasons such as hypertension, intrauterine fetal growth retardation, oligohydramnios etc. Those not in labor were induced with single or multiple doses of misoprostol. The age of gestation was computed from the last menstrual period and also from the early first trimester ultrasound if available. Those who did not have early first trimester or second trimester ultrasound, the age of gestation was based on the last menstrual period (LMP). Stillbirths were not included in this study. The sex ratio was calculated using the formula. Sex ratio (Number of males per 100 females $)=($ No. of male births $/$ No. of female births $) \times 100$.

\section{RESULTS}

There were a total of 1625 live deliveries in a period of one year from July 2016 to June 2017. Lowest number of deliveries on the month of December and January was due to some unavoidable circumstances in the hospital. A total of 120 were preterm deliveries (born before 37 weeks age of gestation), 1238 were term (Between 37 weeks till 40 weeks and 6 days) deliveries and 267 were post term (Beyond 41 weeks of age of gestation) deliveries.

Table1: Total number of deliveries at different age of gestation (AOG) from July 2016 to June 2017

\begin{tabular}{|c|c|c|c|c|c|c|c|c|c|c|}
\hline \multirow[t]{2}{*}{ Month } & \multicolumn{2}{|c|}{$\begin{array}{l}\text { Total de- } \\
\text { liveries }\end{array}$} & \multicolumn{2}{|c|}{$\begin{array}{c}<37 \\
\text { weeks } \\
\text { AOG }\end{array}$} & \multicolumn{2}{|c|}{$\begin{array}{l}>37 \text { to } 40 \\
\text { weeks and } \\
6 \text { days } A 0 G\end{array}$} & \multicolumn{2}{|c|}{$\begin{array}{c}=/>41 \\
\text { weeks } \\
\text { AOG }\end{array}$} & \multicolumn{2}{|c|}{$\begin{array}{c}=/>42 \\
\text { weeks } \\
\text { AOG }\end{array}$} \\
\hline & $\mathbf{n}$ & $\%$ & n & $\%$ & n & $\%$ & n & $\%$ & $\mathbf{n}$ & $\%$ \\
\hline July & 175 & 100 & 13 & 7.42 & 140 & 81.14 & 18 & 10.28 & 4 & 2.28 \\
\hline Aug & 137 & 100 & 11 & 8.02 & 107 & 78.10 & 16 & 11.67 & 3 & 2.18 \\
\hline Sept & 85 & 100 & 6 & 7.05 & 69 & 81.17 & 8 & 9.41 & 2 & 2.35 \\
\hline Oct & 81 & 100 & 8 & 9.87 & 63 & 77.77 & 7 & 8.23 & 3 & 3.70 \\
\hline Nov & 64 & 100 & 5 & 7.81 & 56 & 87.50 & 2 & 3.12 & 1 & 1.56 \\
\hline Dec & 5 & 100 & 0 & 0 & 5 & 100 & 0 & 0 & 0 & 0 \\
\hline Jan & 17 & 100 & 0 & 0 & 16 & 94.11 & 1 & 5.88 & 0 & 0 \\
\hline Feb & 193 & 100 & 12 & 6.21 & 133 & 68.91 & 42 & 21.76 & 6 & 3.10 \\
\hline March & 248 & 100 & 23 & 9.27 & 178 & 71.77 & 40 & 16.12 & 7 & 2.82 \\
\hline April & 198 & 100 & 11 & 5.55 & 149 & 75.25 & 34 & 17.17 & 4 & 2.02 \\
\hline May & 204 & 100 & 15 & 7.35 & 155 & 75.98 & 28 & 13.72 & 6 & 2.94 \\
\hline June & 218 & 100 & 16 & 7.33 & 167 & 76.60 & 31 & 14.22 & 4 & 1.83 \\
\hline TOTAL & 1625 & 100 & 120 & & 1238 & & 227 & & 40 & \\
\hline
\end{tabular}

Among 1625 deliveries, there were 845 male babies and 780 female babies. Highest number of male birth was seen in the month of April 2017 which was 119 (60.10\%). The sex ratio was as high as 150.63 also in the month of April of 2017. The overall sex ratio was 108.33.

Table 2: Total number of male and female babies per month

\begin{tabular}{|c|c|c|c|c|c|c|c|}
\hline \multirow[t]{2}{*}{ Month } & \multicolumn{2}{|c|}{$\begin{array}{c}\text { Total } \\
\text { deliveries }\end{array}$} & \multicolumn{2}{|c|}{ Males } & \multicolumn{2}{|c|}{ Females } & \multirow[t]{2}{*}{$\begin{array}{c}\text { Sex } \\
\text { ratio }\end{array}$} \\
\hline & $\mathbf{n}$ & $\%$ & $\mathbf{n}$ & $\%$ & $\mathbf{n}$ & $\%$ & \\
\hline July & 175 & 100 & 83 & 47.42 & 92 & 52.57 & 90.21 \\
\hline Aug & 137 & & 72 & 52.55 & 65 & 47.44 & 110.76 \\
\hline Sept & 85 & & 38 & 44.70 & 47 & 55.29 & 80.85 \\
\hline Oct & 81 & & 41 & 50.61 & 40 & 49.38 & 102.5 \\
\hline Nov & 64 & & 30 & 46.87 & 34 & 53.12 & 88.23 \\
\hline Dec & 5 & & 2 & 40 & 3 & 60 & 66.66 \\
\hline Jan & 17 & & 10 & 58.82 & 7 & 41.17 & 142.85 \\
\hline Feb & 193 & & 100 & 51.81 & 93 & 48.18 & 107.52 \\
\hline March & 248 & & 133 & 53.62 & 115 & 46.37 & 115.65 \\
\hline April & 198 & & 119 & 60.10 & 79 & 39.89 & 150.63 \\
\hline May & 204 & & 107 & 52.45 & 97 & 47.54 & 110.30 \\
\hline June & 218 & & 110 & 50.45 & 108 & 49.54 & 101.85 \\
\hline TOTAL & 1625 & & 845 & & 780 & & 108.33 \\
\hline
\end{tabular}


Fig 1: Male and female babies born in each month during the study

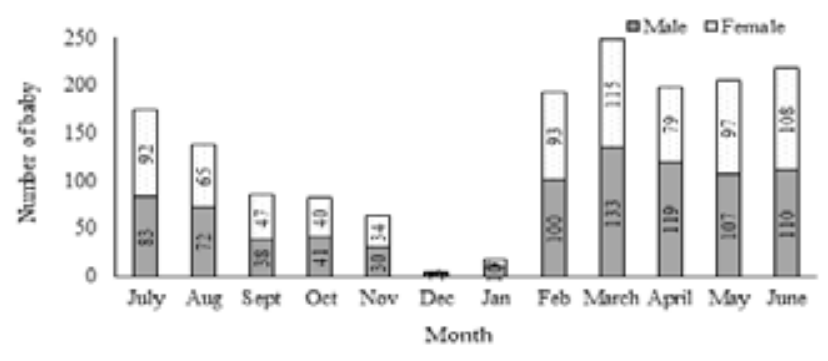

There were a total of 787 primaparous women and 838 multiparous women. Primipara had more female birth than male with a sex ratio of 81.75 . In the case of multipara women, irregardless of the history of previous abortions or stillbirth or fetal death, they had more male births with the sex ratio of greater than 120 .

Table 3: Sex ratio of the baby calculated from the total deliveries during the study period

\begin{tabular}{|c|c|c|c|c|}
\hline Parity & Males & Females & Total & Sex ratio \\
\hline Primipara & 354 & 433 & 787 & 81.75 \\
\hline $\begin{array}{l}\text { Multipara } \\
\text { with previous } \\
\text { abortion, fetal } \\
\text { death }\end{array}$ & 175 & 139 & 314 & 125.89 \\
\hline $\begin{array}{l}\text { Multipara with } \\
\text { no previous } \\
\text { abortion or } \\
\text { fetal death }\end{array}$ & 286 & 238 & 524 & 120.16 \\
\hline
\end{tabular}

\section{DISCUSSION}

Supposedly the sex ratio of human is approximately $1: 1$. But due to higher female fetal mortality ${ }^{8}$, the sex ratio at birth worldwide is commonly thought to be 107 boys to 100 girls $^{9}$ and as previously stated it is 105 as per WHO. Thus, average national sex ratio at birth (SRB) in humans is slightly male biased (105 males per 100 males), with remarkable deviation for some countries ${ }^{10}$.

The number of new born males slightly outnumber new born females because as they grow up, men are at a higher risk of dying than women not only due to sex differentials in natural death rates, but also due to higher risk from external causes (accidents, injuries, violence, war casualties). Thus, the sex ratio of total population is expected to equalize. Graunt described a net excess of male births in his study ${ }^{11}$. By the late 1800 s, there were more males than females die during later pregnancy ${ }^{12}$.
Nonetheless, the demographic and genetic dynamics of the sex ratio from conception to birth are poorly resolved. In our study the sex ratio at birth was around 108 which means there were 108 males for every 100 female births. This number is definitely higher than 105 threshold stated by WHO.

Some scholars have suggested that countries considered to have significant practices of prenatal sex-selection are those with birth sex ratios of 108 and above (selection against females) and 102 and below (selection against males), although this assumption has been questioned by some scholars ${ }^{13}$. A study done in Kaski and Tanahun, the two hill districts in the Western developmental region showed that the sex ratio was adverse in Kaski while it was normal in Tanahun ${ }^{14}$, and most of our patients belonged to Pokhara city which belongs in Kaski district.

Another study conducted in India showed that the sex ratio was 972 females per 1,000 males in primipara, which decreased to 879 females per 1,000 males in second para and further reduced to 784 females per 1,000 males in third para. With increase in parity, there was decline in number of females per 1,000 males $^{15}$ which was also the case in this study.

The current study showed that primipara delivered more female babies while multipara had delivered more male babies than female babies with sex ratio of 81.75 in primipara while it was more than 120 in multipara regardless of the status of previous deliveries. The causes for abortions or fetal death were not identified in this study due to the retrospective nature of the study.

Social outlook for sex preference is more male sex preference is found in multigravida with previous female baby. Male sex preference was also found in primigravida and multigravida with previous male baby but in relatively low percentage ${ }^{16}$. Numerous studies done in Nepal has long been showing decreasing number of female births ${ }^{17,18}$ with sex ratio of much higher than 108 of this study.

Multiple factors have been linked to the sex ratio of the newborn such as age of both parents and ecological factors, regional variation, demographic factors ${ }^{19,20,21}$. Few studies have shown no links to these factors. These factors are not included in the study.

\section{CONCLUSIONS}

Overall there were more male births than female. But in primiparous women more female babies were born 
unlike in multipara. There is definitely a need of in depth study to identify the cause for the skewed value. The sex of the fetus is easily identified without a hassale albeit the law has prohibited it. With stronger law and strict action, most likely we can curb the sex ratio at birth to adjustable level. The society needs to acknowledge that high sex ratios at birth will adversely affect the fertility patterns causing the imbalance in the overall development of the community.

\section{REFERENCES}

1. Pham BN, Hall W, Hill PS, Rao C. Analysis of sociopolitical and health practices influencing sex ratio at birth in Viet Nam. Reprod Health Matters. 2008; 16(32): 176-84.

2. Mathews TJ, Hamilton BE. Trend analysis of the sex ratio at birth in the United States. Natl Vital Stat Rep. 2005; 53(20): 1-17.

3. https://knoema.com/WBGS2014Nov/genderstatistics-november-2014?tsId=1380630

4. United Nations Population Funds: India (Internet). 2011. Trends in sex ratio at birth and estimates of girls missing at birth in India (2001-2008). http:// www.unfpa.org. Accessed 15 June 2012.

5. Frost MD, Puri M, Hinde PRA. Falling sex ratios and emerging evidence of sex-selective abortion in Nepal: Evidence from nationally representative survey data. BMJ Open. 2013; 3: e002612. doi: 10.1136/ bmjopen-2013-002612

6. Gu B, Roy K. Sex ratio at birth in China, with reference to other areas in East Asia: What we know. Asia Pac Popul J. 1995 Sep; 10(3): 17-42.

7. Klasen S. World Dev. 1994; 22: 944-948

8. Orzack, Steven Hecht; Stubblefield, J. William; Akmaev, Viatcheslav R.; Colls, Pere; Munné, Santiago; Scholl, Thomas; Steinsaltz, David; Zuckerman, James E. "The human sex ratio from conception to birth". Proceedings of the National Academy of Sciences. 2015; 112(16): E2102-E2111. doi:10.1073/ pnas.1416546112

9. "Sex ratio". The Central Intelligence Agency of the United States. Archived from the original on 30 November 2013.
10. Parazzini F, La Vecchia C, Levi F, Franceschi S. Trends in male : female ratio among newborn infants in 29 countries from five continents. Hum Reprod. 1998; 13: $1394-1396$.

11. Campbell RB, John Graunt, John Arbuthnott, and the human sex ratio. Hum Biol. 2001; 73(4): 605-610.

12. Nichols JB (1907). The numerical proportions of the sexes at birth. Mem Am Anthropol Assoc. 2008 July; 1(4): 247-300.

13. James WH. (July 2008). "Hypothesis: Evidence that Mammalian Sex Ratios at birth are partially controlled by parental hormonal levels around the time of conception". Journal of Endocrinology. 198 (1): 3-15. doi:10.1677/JOE-07-0446

14. Puri M, Tamang A. Understanding factors influencing adverse sex ratios at birth and exploring what works to achieve balance: the situation in selected districts of Nepal. CREHPA, Kathmandu, Nepal (2015) xvi + 52 pp.

15. Warade Y, Balsarkar G, Bandekar P. A study to review sex ratio at birth and analyze preferences for the sex of the unborn. J Obstet Gynaecol India. 2014 Feb; 64(1): 23-26.

16. Srivastava S, Sharma S, Kharkwal S, Singh M. Demographic masculinization with increasing parity and outlook of sex preference in Bundelkhand Region, India. Int J Reprod Contracept Obstet and Gynecol. 2015 Dec; 4(6): 1993-1996. DOI: http://dx.doi. org/10.18203/2320-1770.ijrcog20151301

17. Adhikari N, Ghimire A, Ansari I. Sex preference in urban Nepal. J Instit Med. 2008; 30: 19-23.

18. Aryal S, Kalakheti B. Sex Ratio at Birth in a Tertiary Care Hospital in Western Nepal are the Trends Changing? J Nepal Paediatr Soc. 2016; 36(1): 68-71.

19. Pavic D. Factors affecting sex ratio at birth in Croatia 1998-2008. J Biosoc Sci. 2012; 44(3): 357-64.

20. Rueness J, Vatten L, Eskild A. The human sex ratio: effects of maternal age. Hum Reprod. 2012; 27(1): 283-7.

21. Garenne M. Poisson variations of the sex ratio at birth in African demographic surveys. Hum Biol. 2008; 80(5): 473-82. 